\title{
Morphometric and Morphotectonic Characteristics of Sürgü and Çardak Faults (East Anatolian Fault Zone)
}

\author{
Musa Balkaya ${ }^{1, *}$, Süha Özden², H. Serdar Akyüz ${ }^{3}$ \\ ${ }^{1}$ Department of Geology Engineering, School of Graduate Studies, Çanakkale Onsekiz Mart University, Çanakkale, Turkey \\ ${ }^{2}$ Department of Geology Engineering, Faculty of Engineering, Çanakkale Onsekiz Mart University, Çanakkale, Turkey \\ ${ }^{3}$ Department of Geological Engineering, Faculty of Mines, İstanbul Technical University, İstanbul, Turkey
}

Article History

Received: $\quad 20.05 .2021$

Accepted: $\quad 02.08 .2021$

Published: $\quad 20.09 .2021$

Research Article

\begin{abstract}
Within the framework of this study, morphotectonic and structural characteristics of the Sürgü and Çardak faults, the northern branch of the East Anatolian Fault Zone (EAFZ) between Çelikhan and Göksun, were investigated with scrutiny. Further, the results obtained with morphotectonic assessments supported and fortified with a thorough literature review and field studies; thereby, geological features of the region have been analyzed immaculately. The Sürgü and Çardak faults were mapped with special attention to the lithological, structural, and geomorphological features of the study area. Investigations along the Holocene river valleys along the approximately $\mathrm{E}-\mathrm{W}$ trending Sürgü and Çardak faults evidently indicate that these faults represent sinistral active fault morphology. In terms of morphometric assessments, mountain front sinuosity (Smf), the Valley Floor Width-to-Valley Height ratio (Vf) and Stream Length-Gradient Index (SL) were employed along the mountain-piedmont junction and on the drainage network. Recorded Smf values range from 1.21 to 1.48 , and average $\mathrm{Vf}$ rates are between 0.20 and 1.12, which typically indicate high tectonic activity for the Sürgü and Çardak faults. SL indice exercised along the 10 valleys in the study area, the recorded values vary between 5.8 and 1330.0; besides, the higher anomalies are recorded adjacent to the Sürgü and Çardak faults. Implemented morphotectonic investigations and evaluations indicate that the Sürgü and Çardak faults play a key role in the morphotectonic evolution of the region.
\end{abstract}

Keywords - Active tectonic, East Anatolian Fault Zone, morphometric indices, morphotectonic, Sürgü and Çardak faults

\section{Introduction}

Earthquakes are one of the most destructive natural disasters that have certain consequences on mankind's life, economy, and social communities. Densely populated civic settlements dominated with active faults are prone to destructive earthquakes; hence, people living in nearby regions should exercise preparations in advance against earthquakes. Within the boundaries of the study area, there exist active deformation zones with high earthquake potential such as the Southeastern Anatolia Thrust Belt and the East Anatolian Fault Zone (EAFZ), which are generated as a result of the collision between the African-Arabian and Eurasian plates in the north-south orientation. Immaculate examination of the morphotectonic properties of the aforementioned zones can facilitate our understanding of the characteristic features of these faults.

Performed investigations up to the contemporary era, show that the manifold activities along the faults generate different geomorphologic features on the earth's crust (Keller and Pinter, 2002). Morphometric discipline is one of the most popular and effective measures to interpret and evaluate the connotations of these features. There exist many geological, geomorphological, and tectonic studies on the northern branch of the EAFZ between Çelikhan and Göksun (Perinçek and Kozlu, 1984; Yılmaz, 2002; Westaway, 2004; Koç, 2005; Sunkar, Günek, \& Canpolat, 2008; Duman and Emre, 2013; Koç and Kaymakçı, 2013; Emre et al., 2016). Nonetheless,

\footnotetext{
1 (D) musabalkaya@ksu.edu.tr

2 (D) ozden@ comu.edu.tr

3 (D) akyuz@itu.edu.tr

*Sorumlu Yazar / Corresponding Author
} 
morphotectonic investigations remained unprecedented in this area. Hence, within the architecture of this original research article morphotectonic characteristics of the 160-km-long deformation zone including the Sürgü and Çardak fault segments have been discovered and analyzed (Figure 1).

The Sürgü and Çardak faults have been analyzed rigorously in order to form a basis for morphotectonic studies. The Sürgü and Çardak faults runs through numerous settlements such as Çelikhan, Kurucaova, Sürgü, Nurhak, Barış, Ekinözü, Ericek, Çardak, Gücüksu, and Göksun. Thus, discovering and revealing the earthquake hazard potential of the Sürgü and Çardak faults is of utmost importance in terms of human life, industrial, and urban planning and engineering studies.

The foremost goal of this study is to examine and analyze the Sürgü and Çardak fault segments with morphotectonic discipline. Consequently, morphotectonic assessments exercised for this purpose. Acquired data represent valuable information about the Late Quaternary activity of the Sürgü and Çardak faults and the impacts of these faults on the morphologic and topographic evolution of this domain. In addition, mountainpiedmont junctions, valleys, and drainage networks associated with the Sürgü and Çardak faults evaluated with quantitative morphometric indice methods, which cater good insight about the tectonic activity of these faults.

In what follows, with pursuing a general to specific mean, first, the EAFZ is explained, and then the Sürgü and Çardak faults, which are a part of the northern branch of the EAFZ, are discussed in detail. Finally, compiled information about the Geology around the Sürgü and Çardak faults is presented.

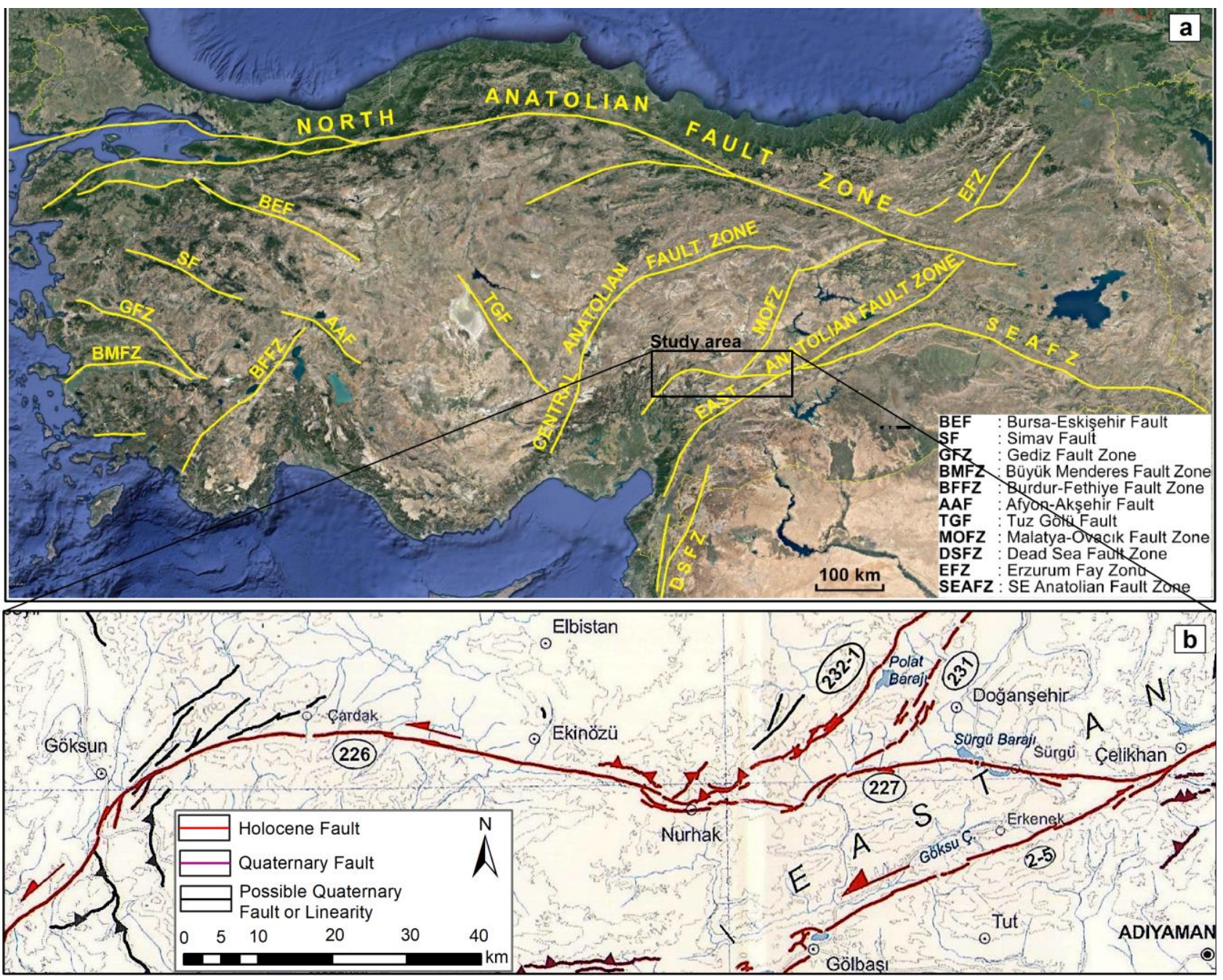

Figure 1. (a) Location of the study area on the active fault maps of Turkey (simplified from Emre et al (2013)). (b) Orientation of active faults in the study area (Emre et al., 2013;226: Çardak fault, 227: Sürgü fault, 231: Doğanşehir fault, 232-1: Malatya Fault-Akçadağ segment). 


\subsection{The East Anatolian Fault Zone}

The EAFZ is one of the most important and highly active faults of Turkey; thereby, many geological, geomorphological, tectonic, and paleoseismological studies have been carried out along the fault zone. The East Anatolian Fault Zone prolongs for approximately $580 \mathrm{~km}$ length with a dominant sinistral sense of motion (Şaroğlu, Emre, \& Kuşçu, 1992). The general geometry of the fault zone predominantly shaped by a series of active faults which are positioned with parallel, subparallel, and oblique orientations (Şengör, 1980; Nalbant, McCloskey, Steacy, \& Barka, 2002; Özdemir and İnceöz, 2003; Herece, 2008; Kop et al., 2014; Emre et al., 2016). The EAFZ starts from Karlıova in the northeast, runs through the Kahramanmaraş and ultimately ends around the Dead Sea Fault. The EAFZ indicate a single strand strike-slip fault geometry until the west of Çelikhan, from this point onwards, nevertheless, it is switched into several bifurcations where deformation accommodates within a wide zone (Duman and Emre, 2013). The main branch of the EAFZ between Karlova and Antakya was split into 7 segments by Emre et al. (2016). These are namely: Karlıva, Ilıca, Palu, Pötürge, Erkenek, Pazarcik and Amanos segments (Figure 2).

From Çelikhan to Iskenderun Bay, the northern branch of the Eastern Anatolian Fault Zone prolongs for about $380 \mathrm{~km}$ and represents characteristic features of an active left-lateral strike-slip fault along its orientation. From Northeast to Southwest, this fault zone is divided into 9 segments: Sürgü, Çardak, Savrun, Çokak, Yakapınar, Andırın, Toprakkale, Yumurtalık and Karataş segments (Duman and Emre, 2013; Emre et al., 2016).

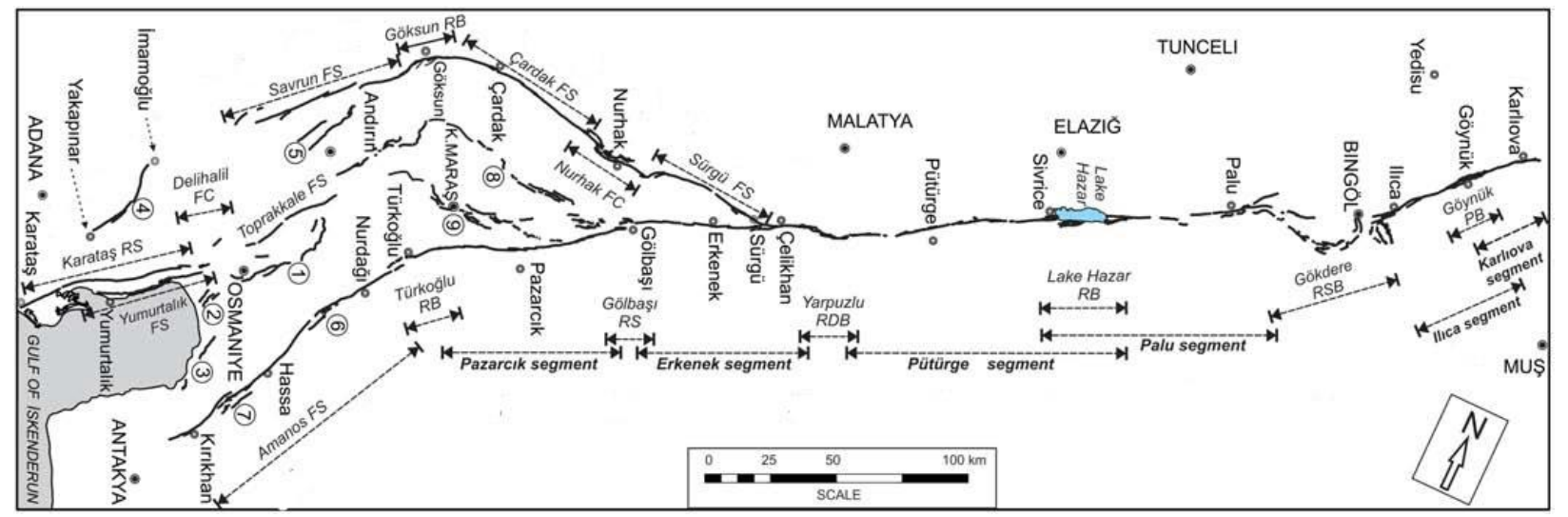

Figure 2. The figure shows the general geometry of the Eastern Anatolian Fault System (the main branch, northern branch and associated fault segments; Duman and Emre, 2013). Abbreviations: FS, fault segment; $\mathrm{RB}$, releasing bend; RS, releasing stepover; RDB, restraining double bend; RSB, restraining bend; PB, paired bend; (1) Düziçi-Osmaniye fault segment; (2) Erzin fault segment; (3) Payas fault segment; (4) Yakapınar fault segment; (5) Çokak fault segment; (6) Islahiye releasing bend; (7) Demrek restraining stepover; (8) Engizek fault zone; (9) Maraş fault zone.

Although theories regarding the onset of deformation along the EAFZ is controversial, there is a consensus on the Late Pliocene age among researchers (Şaroğlu et al., 1992; Westaway, 2004; Yönlü, Altunel, Karabacak, \& Akyüz, 2013). Geodetic data indicate approximately $10 \mathrm{~mm} / \mathrm{y}$ slip rate throughout the fault zone, yet geological investigations demonstrate that the slip rates vary between 4-11 mm/y (McClusky et al., 2000; Reilinger et al., 2006, Herece, 2008; Yönlü et al., 2013; Emre et al., 2016). Regarding the displacement and offset measurements along the EAFZ, conducted studies reported 15-27 km of sinistral displacement based on the offset of Firat river and the displacement amount of the pre-Pliocene rocks (Yönlü et al., 2013).

\subsection{The Northern Branch of EAFZ Between Çelikhan and Göksun}

Between Çelikhan and Göksun, the Sürgü and Çardak faults that constitute the northern branch of the EAFZ are the subject of this study (Figure 1). Many studies on this area, defined the Sürgü and Çardak faults as a left lateral strike-slip faults (Perinçek and Kozlu, 1984; Y1lmaz, 2002; Westaway, 2004; Duman and Emre, 2013; Emre et al., 2016). A number of other studies, on the other hand, based on remote sensing methods, field 
observations and fault slip data acclaimed that the Sürgü Fault Zone, which consists of Sürgü and Çardak fault segments, are representing dextral strike-slip kinematic characteristics (Koç, 2005; Sunkar et al., 2008; Koç \& Kaymakç1, 2013). Furthermore, Duman and Emre (2013) based on the recorded systematic offsets along the Holocene drainage networks, stated that there exist $3 \mathrm{~mm} / \mathrm{y}$ and $2.5 \mathrm{~mm} / \mathrm{y}$ of slip throughout the Sürgü and Çardak faults respectively.

\subsubsection{The Sürgü Fault}

The Sürgü fault differentiates from the EAFZ around the west of Çelikhan and runs through the west of Nurhak, enclosing the Nurhak fault complex. The E-W trending Sürgü fault extends approximately for $75 \mathrm{~km}$ and represents active left-lateral strike-slip fault geometry (Perinçek and Kozlu, 1984; Yilmaz, 2002; Westaway, 2004; Duman and Emre, 2013; Emre et al., 2016).

The research conducted by Koç (2005) and Koç and Kaymakçı (2013) on the Sürgü fault, claimed that the western part of the Sürgü fault demonstrate predominant right-lateral strike-slip motion and reverse components, while the eastern part represents prevailing right-lateral strike-slip motion with a normal component, mainly based on evaluated remote sensing methods, field observations, and fault slip data. These two studies declared that the dextral motion of the Sürgü Fault Zone could be explained by the westward escape of the Maraş Block as a result of the N-S collision of the Arabian Plate and the Anatolian Block.

Moreover, another study by Sunkar et al. (2008) contended that the Sürgü Fault Zone and EAFZ are both independent fault zones, and supported the right-lateral motion of the fault zone. Moreover, another study by Sunkar et al. (2008) contend that the Sürgü Fault Zone is an individual fault zone from EAFZ, and interweave the right-lateral motion of the fault zone to this hypothesis. In this paper, the geomorphologic properties of the Kurucaova and its surrounding regions (covering an area of $30 \mathrm{~km}^{2}$ ) located in the south of the Sürgü fault were investigated.

The Y1lmaz (2002)'s study shows that prolonged ridges in the eastern part of the Sürgü fault; and irregular valleys interrupted by the fault at pour point section, and sinistrally offset rivers in the western parts of Sürgü fault are the main distinct morphological structures. A total of $4 \mathrm{~km}$ left-lateral offset was detected along the fault; therefore, even in the premier context, the fault must have developed in the Pliocene period (Y1lmaz, 2002). Although the eastern extension of the Sürgü fault up to Sürgü town is dipping in the north direction, the fault segment in the west of Sürgü is dipping 850 southwards and its slope angle decreases gradually towards the depth (Taymaz, Eyidoğan, \& Jackson 1991; Yılmaz, 2002).

Duman and Emre (2013) claimed that the 17-km-long and 1-km-wide zone located in the eastern part of Sürgü fault is characterized by a shutter ridge. This distinctive structure shows that the Sürgü fault is effective in shaping the morphology of the region. Then the fault continues for $20 \mathrm{~km}$ westward along the southern branch of the Sürgü river valley, where tributaries and intervening ridges are systematically offset. The western margin of the fault is represented by two sub-parallel faults at a $5 \mathrm{~km}$ distance and then meets the Nurhak fault complexity (Duman and Emre, 2013).

Duman and Emre (2013) investigations represent that a Holocene aged alluvial fan was offset by the surface rupture, indicating that the Holocene surface faulting occurred along the Sürgü fault during a large earthquake. However, the same research also states that the 1986 Sürgü earthquakes with magnitudes of 5.6 and 5.8 are not associated with a surface deformation on the Sürgü fault.

\subsubsection{The Çardak Fault}

The $~ 85$-km-long Çardak fault represents a concave geometry between Nurhak and Göksun. In about 10 $\mathrm{km}$ east of Ericek (Göksun), the fault jumps towards the right direction over a nearly $500 \mathrm{~m}$ wide stepover, and then fault tips bifurcates into two branches toward east $(35 \mathrm{~km})$ and west $(50 \mathrm{~km})$ directions. By and large, starting from the west of Nurhak district the eastern section of the fault represents a linear geometry. The 
Çardak fault disrupts the creeks flowing on the wide alluvial fan deposits between Barış and Gözpınar by offsetting them from 100 to 135 meters. In the west of Ekinözü, this fault offset Ceyhan Valley $3 \mathrm{~km}$ to the left (Duman and Emre, 2013). In addition, Duman and Emre (2013) stated that the 50-km-long western section of the Çardak fault cuts the folds and older thrusts and exhibits an evident active left-lateral fault morphology; besides, in this part, the Holocene river valleys and bedrocks displaced and offset by the fault.

\subsection{Geology of the Study Area}

In order to map the geological formations and structural features in the study area, detailed investigations were conducted with thorough observations during field studies around the fault zone. The orientation of the fault was observed during the field study based on the current Active Fault Map of Turkey prepared by the General Directorate of Mineral Research and Exploration (MTA) in 2013 (Emre et al., 2013). During different intensive field trips, the Sürgü and Çardak faults were mapped with special attention to the lithological, structural, and geomorphological features of the study area (Figure 3).

The geological map of the 160-km-long and nearly 15-km-wide zone enclosing the E-W trending Sürgü and Çardak faults was prepared (Figure 3). During the map preparation stages, the 1/100.000 scale geological map of the Elbistan-L37 and L38, Malatya-L39 and L40, Gaziantep-M37 and M38, Şanlıurfa-M39 and M40 sections published by the MTA (2014) were utilized. Since the Sürgü and Çardak faults run through the edges of the aforementioned map sections, eight 1/100.000 scale geologic maps were combined and the basis was formed. Lithological units of the study area are divided into 3 main groups: namely pre-Miocene, Miocene, and post-Miocene units. Pre-Miocene basement rocks, which blanket a large proportion of landscape within the study area, consists of magmatic, metamorphic, and sedimentary rock types. Magmatic rock units, including basalt, diabase, spilitic basalt, agglomerate, and volcano-sedimentary rocks exposed to the east of the study area.

Metamorphic rocks, however, are prevailing throughout the whole study area, and rock samples such as marble, recrystallized limestone, schist, calcschist, mica schist, serpentine, peridotite, gabbro, metagabbro, gneiss, augen gneiss, quartzite, phyllite, and amphibolite are frequently exposed at different sections of the area. Sedimentary rocks within the pre-Miocene basement rocks spread throughout the study area. Moreover, sedimentary rock units like limestone, conglomerate, sandstone, mudstone, neritic limestone, dolomite, siltstone, claystone, and shale are also observed sporadically in the study area (Bedi and Yusufoğlu, 2018; Çoban and Dalkı1ıç, 2018; Usta et al., 2018).

In the study area, the Miocene units disseminate at the south of the Çardak fault; moreover, they are enumerated as lower Miocene sandstone-mudstone-limestone unit, Middle Miocene sandstone-mudstone-limestone unit, Upper Miocene claystone-sandstone unit, and Upper Miocene-Pliocene sandstone-mudstone-limestone units (Baydar and Yergök 1996; Usta et al., 2018).

Pliocene-Quaternary units in the study area are Pliocene conglomerate-sandstone-mudstone unit observed in the north of Sürgü dam, Pliocene sandstone-mudstone-limestone unit detected in NW of Ekinözü district located around the north of the Çardak fault, Plio-Quaternary conglomerate-sandstone-mudstone unit observed around Kurucaova to the south of the Sürgü fault and the Pliocene-Pleistocene alluviums seen in the north of the western edge of the Sürgü fault (Tatlar; Usta et al., 2018).

Within the study area, the faults cut and run throughout valleys and basins where Quaternary units lie across them. These units can be enumerable as alluvium, debris flows, young and old alluvial fan deposits. The alluvium deposits exposed along the valleys and faults throughout the study area are generally composed of poorly cemented gravel, sand, silt, clay and mud. Old Alluviums, on the other hand, usually consist of poorly consolidated gravel, sand, clay and mud that lies along river terraces and valleys delimited by high hills. These units are observed around the Nurhak district within the study area. 

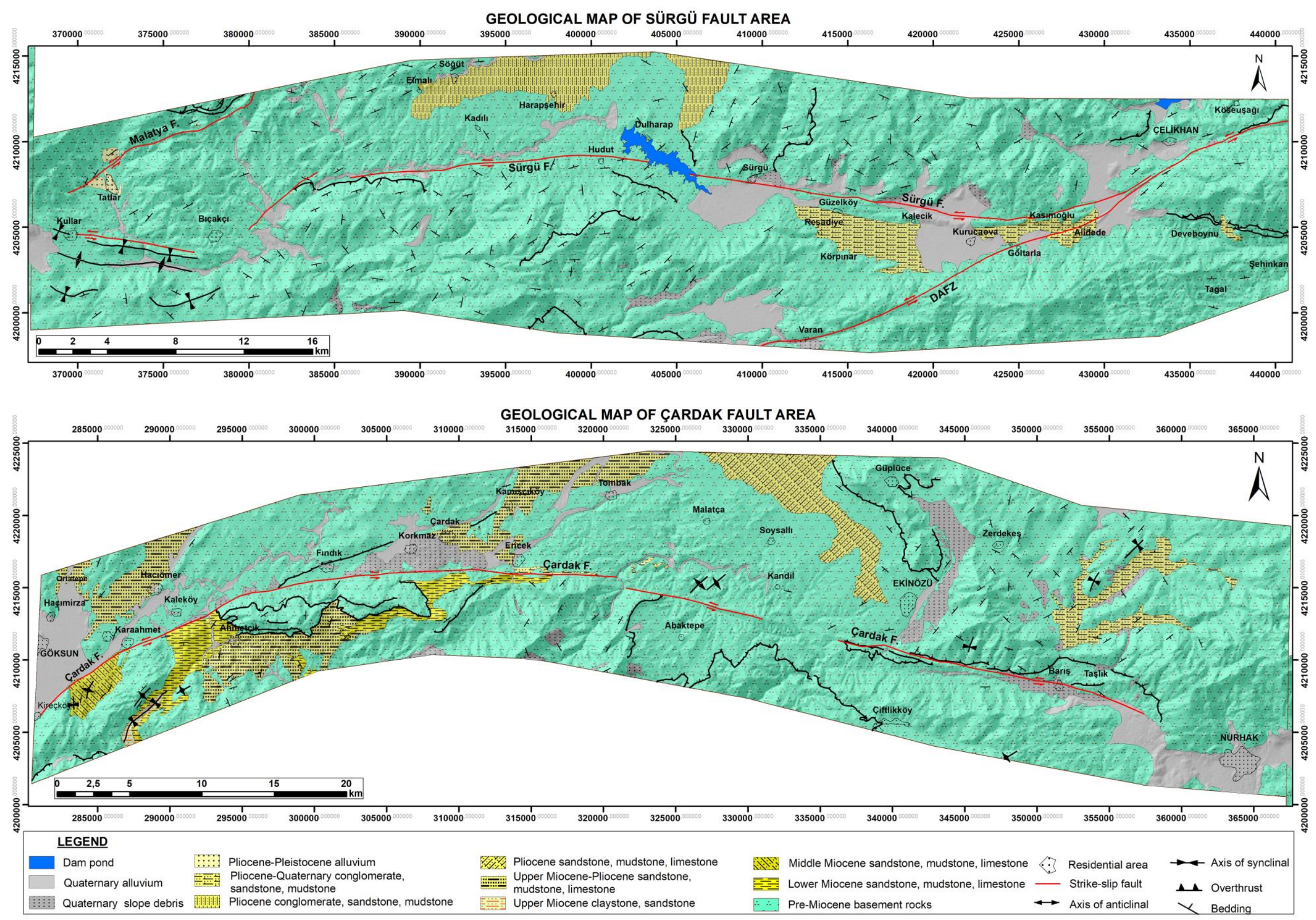

Figure 3. Simplified geology map of the study area (compiled from 1/100.000 scale sheets of MTA (2014) geology database) 
Alluvial fans are observed along the Sürgü Fault Zone in the study area. The alluvial fans are predominantly composed of conglomerate, sandstone, siltstone with caliche, and mudstone from the apex toward the toe (Bedi and Yusufoğlu, 2018). The Old Alluvial Fan is observed in Reşadiye and Kurucaova villages in the southern sections of the Sürgü fault. These are made up of gravel, sand, silt, and clay-sized materials that were transported from high altitudes by floods. Debris flows mostly detected adjacent to the faults within the study area, they consist of poorly sorted and consolidated blocks, pebbles, and negligible amounts of sand and clay which is formed as a result of sediment flux through steep spurs (Usta et al., 2018).

\section{Materials and Methods}

Morphometric analysis is one of the imperative tools to evaluate and assess the impacts of tectonic activity on the development of geomorphic processes and earth crust's morphology (Keller and Pinter, 2002). To investigate morphological properties of any fault zone and to implement morphometric analysis in the study area, a Digital Elevation Model (DEM) with $10 \mathrm{~m}$ ground resolution should be generated utilizing 1/25000 scale digital topographic maps enlisting the ArcGIS program. DEM data can also be generated by downloading raster data (satellite image) with $12.5 \mathrm{~m}$ or $30 \mathrm{~m}$ resolutions form from different international resources (e.g. NASA or ESA).

In order to perform morphotectonic investigations, the Digital Elevation Model (DEM) of the study area generated from Alos Palsar data (ASF, 2020) with $12.5 \mathrm{~m}$ ground resolution, the data were downloaded from https://search.asf.alaska.edu/\#/. With the utilization of the identical data, the Hill-Shade map of the study area was produced with the ArcGis 10.7 software, and then Sürgü and Çardak faults were integrated into the map. Next, with the aid of ArcHydro Tools within the ArcGis software, the drainage basins and stream networks of the study area were plotted on the DEM data.

Within the scope of this paper, prior to the morphometric indice evaluation, the Rock Strength classification of lithological units within the study area was defined. Then morphometric indice calculations were exercised within the study area. These investigations include implementation of mountain front sinuosity (Smf) along the mountain-piedmont junctions, Valley Floor Width-to-Valley Height ratio (Vf), and Stream LengthGradient (SL) indice calculations on the drainage networks and basins which cater invaluable information regarding the geomorphologic evolution of the region and the impacts of the tectonic framework on this evolution.

\subsection{Rock Strength}

Since the rock resistance of different lithologies against erosion is vital regarding the interpretation of morphometric indice calculations and results, the rock strength of the different geologic units in the study area are defined. In this context, the lithological units in the study area are split into 5 classes considering the mechanical rock resistance classification defined by Selby (1980) (e.g. Yıldırım, 2014; Khalifa, Cakır, Owen, \& Kaya, 2018; Sançar, 2018; Topal, 2019). Lithologic units within the study area are classified according to different rock strength categories (i.e. very low strength, low strength, moderate strength, high strength and very high strength).

\subsection{Mountain Front Sinuosity (Smf)}

Mountain front sinuosity is one of the most effective tools to define tectonically active mountain fronts from inactive mountain fronts and it is represented by this formula: $\mathbf{S m f}=\mathbf{L m f} / \mathbf{L s}$ (Keller and Pinter, 2002). Where Lmf is the total length of the lineation throughout the topographic contour along the mountain front and Ls is the distance between two margins of the straight line along the mountain front (Figure 4a). This indice is beneficial to assess the rate of tectonic activity through the mountain front (Keller and Pinter, 2002). Bull (2008) stated that if the Smf indice is below 1.4 it represents a low rate and if the quantity is between 1.4 and 3, it depicts a medium range. Low and medium Smf indexes are an indicator of high tectonic activity along 
mountain fronts (Keller and Pinter, 2002). In the study area, a total of 7 Smf calculations were performed, 4 on the Sürgü fault and 3 on the Çardak fault.

\subsection{Valley Floor Width-to-Valley Height Ratio (Vf)}

The valley floor width to valley height ratio indice defines the differences between $U$-shaped flat-floored valleys (with relatively high Vf values) and V-shaped valleys (with relatively low Vf values; Keller and Pinter, 2002). The valley floor width to the valley height ratio is one of the popular tools to evaluate the ongoing tectonic uplift rate in a region and is defined by this formula: $\mathbf{V f}=\mathbf{2}$.Vfw $/[($ Eld-Esc) + (Erd-Esc)] (Keller and Pinter, 2002). Where Vfw indicates the width of the valley floor, Eld and Erd show the heights of the left and right edges of the valley respectively, and the Esc depict valley floor altitude (Figure 4c). Vf indice values are categorized into 3 main classes according to the acquired and evaluated result from different studies by manifold researchers (Silva, Goy, Zazo, \& Bardají, 2003; El Hamdouni, Irigaray, Fernández, Chacón, \& Keller 2008). Thus, Vf values less than 0.5 show high tectonic activity (Class -1), and if the Vf quantity is confined to the $0.5-1$ range, then the tectonic activity is medium (Class-2); finally, Vf values higher than 1 indicate minimum tectonic activity level (Class-3).

\subsection{Stream Length-Gradient Indice (SL)}

Stream length-gradient indice is a powerful tool to evaluate the relationships between tectonic activity, rock resistance, and topography along with bedrock river profiles, and it is represented by this formula: $\mathbf{S L}=\Delta \mathbf{H x L} / \Delta \mathbf{L}$ (Figure 4b; Hack, 1973; Keller and Pinter, 2002). Where SL is stream length-gradient index, $\Delta \mathrm{H}$ is the change in channel altitude, $\Delta \mathrm{L}$ is the channel length of the measured proportion, and $\mathrm{L}$ is the distance from the midpoint of the interested section where the indice is calculated towards upstream of the highest point on profile (Keller and Pinter, 2002; Troiani, Galve, Piacentini, Della Seta, \& Guerrero, 2014). Many studies based on the El Hamdouni et al. (2008)'s work (e.g. Köle, 2016; Saber, Isik, \& Caglayan, 2018) categorized SL indice values into 3 main tectonic groups: namely class 1: $500<$ SL, class 2: $300<$ SL $<500$, and class 3: SL <300. In similar sources, the height ranges culled out in SL calculations range from 100 to 250 meters in those studies (e.g. Troiani et al., 2014; Topal, 2019).

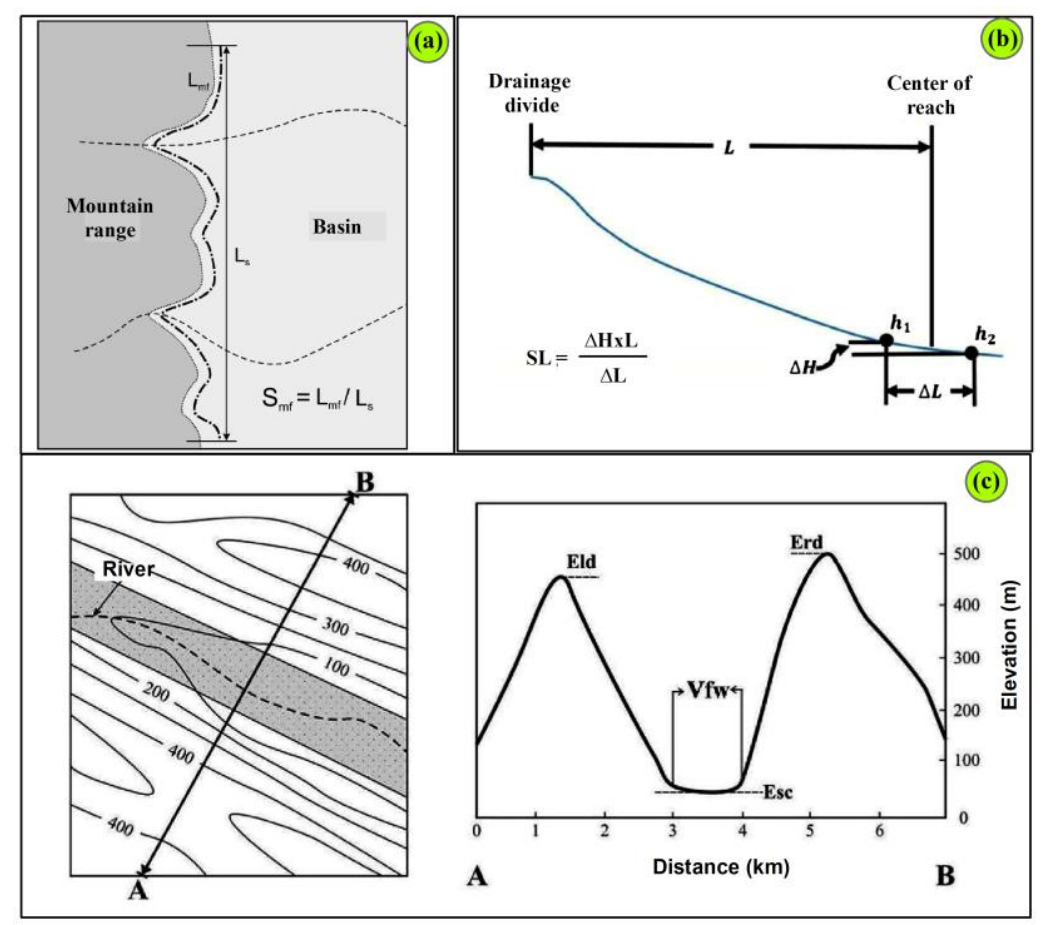

Figure 4. (a): Diagram utilized in the calculation of mountain front sinuosity (Keller and Pinter, 2002). (b): Schematic for the calculation of stream length-gradient indice (Hack, 1973). (c) Parameters used in Vf calculations (Keller and Pinter, 2002). 
The lengths of the calculated valleys in this study are relatively short and vary between 3.803 and 15.123 meters; hence, SL measurement interval values are assigned $10 \mathrm{~m}, 20 \mathrm{~m}$, and $50 \mathrm{~m}$ due to the length of the evaluated valleys. Subsequently, since the aforementioned values regarding the tectonic classification of the SL indice correspond to the large-scale studies, they were reformulated and reduced by half. The SL values of this study were divided into 3 tectonic classes: namely class 1: $250<$ SL, class $2: 150<$ SL $<250$, and class 3 : SL $<150$.

\section{Results and Discussion}

In this research, the morphotectonic properties of the Sürgü and Çardak faults that constitute a small proportion of the northern branch of the EAFZ were investigated. To support the results of the morphotectonic investigations, geologic features of the study area were discovered with a thorough literature review and performed field studies. Morphometric analysis within this area caters information regarding the geomorphologic evolution of the region and the effects of tectonic activity on this evolution.

\subsection{Seismicity of the Sürgü and Çardak Faults}

According to historical and instrumental earthquake records, plenty of earthquakes occurred within the Sürgü and Çardak faults' sphere of the influence (Taymaz et al., 1991; Guidoboni, Comastri, \&, Traina, 1994; Ambraseys, 2009; Duman and Emre, 2013). Over the latest centuries, the most important earthquakes occurred on the EAFZ are; 1513 Pazarcık, 1544 Elbistan, 1822 Antakya, 1866 Karlova, 1872 Antakya, 1874 Gezin, 1875 Sivrice, 1893 Çelikhan, 1905 Pötürge, 1971 Bingöl, 1977 Palu, 1986 Mayıs-Haziran Sürgü, 1998 Ceyhan, January 24, 2020 (M=6.8) Sivrice (Elazı̆ ) earthquakes (Taymaz et al., 1991; Duman and Emre, 2013). Among those events, according to the historical earthquake records, the 1544 Zeytun (Elbistan) earthquake event occurred around the Çardak fault with a magnitude of 6.8 (Ambraseys, 2009; Duman and Emre, 2013). As a result of this event, the previous settlement of Armenian's the Zeytun town (today known as Süleymanlı village in the Kahramanmaraş) and a part of Elbistan were demolished (Ambrassy, 2009). Contemplating all of the aforementioned points and the subtle facts that the Çardak fault runs $23 \mathrm{~km}$ north of Süleymanlı and $20 \mathrm{~km}$ south of Elbistan, we can boil down the conclusion that, most probably, the Çardak fault was responsible for the 1544 earthquake.

Based on the historical earthquake records (Guidoboni et al., 1994; Ambraseys, 2009), the Arabissus (presently known as Elbistan/Kahramanmaraş) settlement, established by Maurice, a former emperor, was demolished two times as a result of the two major earthquakes in 584/585 $\mathrm{AD}$ and $587 \mathrm{AD}$ respectively. Considering the location of Elbistan and the position of the active faults around the neighbouring regions, it is exorbitantly liable that at least one of the 584/585 $\mathrm{AD}$ and $587 \mathrm{AD}$ earthquakes were generated by the Çardak fault.

Earthquake records during the instrumental period demonstrate two destructive earthquakes events occurred around the north of the Sürgü fault, in the vicinity of Doğanşehir, on 5th of May (Ms=5.8) and 6th of June (Ms=5.6) respectively (Taymaz et al., 1991; Y1lmaz, 2002; Duman and Emre, 2013). Through instrumental period, there also exist earthquake records on the Çardak fault as well. According to the data represented by the Boğaziçi University Kandilli Observatory and Earthquake Research Institute National Earthquake Monitoring Center (KOERI-RETMC, 2021), in 1922, in the southwest of Ekinözü (Kahramanmaraş), an earthquake event occurred with a magnitude of 5.5; furthermore, in 1978, another event with a magnitude of 5.0 arise in the vicinity of Nurhak (Kahramanmaraş; Figure 5). 


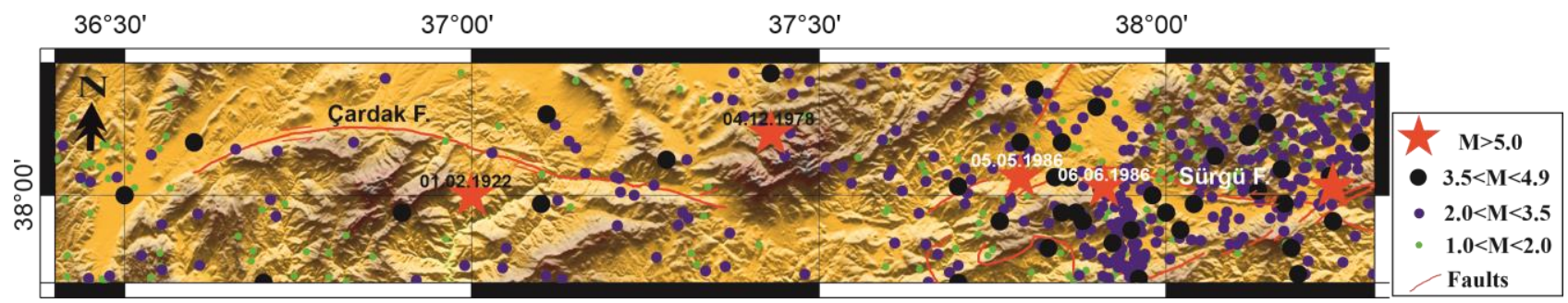

Figure 5. Distribution of the earthquakes within the study area and neighbouring regions throughout the instrumental period (1900-2021; KOERI-RETMC, 2021).

\subsection{Morphometric Analysis}

Offsets along different streams were detected at various locations along the Sürgü and Çardak faults enlisting the field operations, Google Earth images, and the analyzed stream networks on the DEM (Figure 6). Along the valleys located at the east of Sürgü village (Doğanşehir/Malatya), systematic sinistral offsets with a maximum displacement of 330 meters were detected, this phenomenon simply indicates the powerful effect of the Sürgü fault on these stream network (Figure 6a). In the western part of the Sürgü fault, around the south of Tatlar village, a left lateral offset was observed throughout the Tatlar River with approximately $1 \mathrm{~km}$ displacement (Figure 6b). In the central part of the Çardak fault, about $16 \mathrm{~km}$ west of Ekinözü district (Kahramanmaraş), $280 \mathrm{~m}$ of offset detected along the Kılıcinpınar Stream (Figure 6c). Further, at the western margin of the Çardak fault, leftward offsets of up to 216 meters were observed in the streams flowing into Göksun Stream around Aslanbey farm (Göksun/Kahramanmaraş; Figure 6d). Contemplating all of the results and field evidences, it may be stated that the Sürgü and Çardak faults are active left-lateral strike-slip faults.
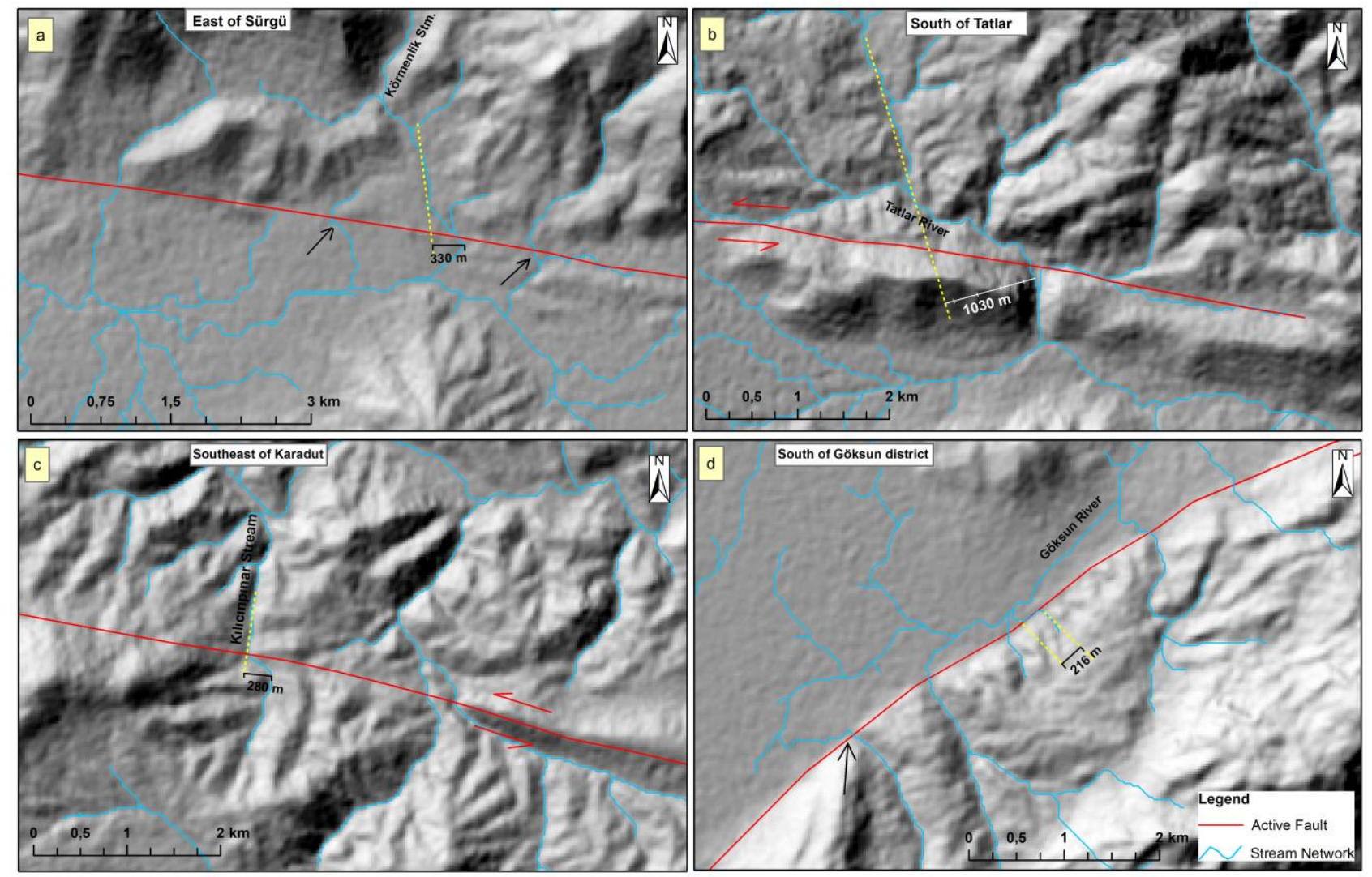

Figure 6. The stream offsets detected throughout the Sürgü fault (a: east of Sürgü district, b: south of Tatlar village) and Çardak fault (c: west of Ekinözü, d: around Aslanbey farm). The black arrows indicate the offsets that were not measured. 
By and large, morphometric indices assessments are exercised to evaluate the impacts of regional tectonic activity. The quantitative outcomes of morphometric data can be utilized to understand the geomorphological evolution of large domains or to contrast different segments of an active fault (Keller and Pinter, 2002; Selçuk, 2016; Topal, Keller, Bufe, \& Koçyiğit, 2016; Basmenji et al., 2021). In this study, morphometric analyzes like Rock Strength Classification, Mountain Front sinuosity (Smf), Valley Floor Width-to-Valley Height Ratio (Vf), Stream Length-Gradient Index (SL) were performed.

\subsubsection{Rock Strength}

According to the rock resistance classification defined by Selby (1980), the lithological units in the study area are classified into 5 categories: namely very low strength (alluvium, debris flow, alluvial fan deposits), low strength (conglomerate, sandstone, limestone, mudstone, siltstone, claystone), medium strength (schist, phyllite, serpentinite), high strength (basalt, diabase) and very high resistant (marble, quartzite, gneiss). Based on this classification, rock units with very high and low strengths cover a great proportion in the study area. Rocks with high resistance are observed only in the SE of the Sürgü fault. Rocks with the medium are sporadic throughout the study area. Very low strength lithological units, however, are observed along valleys and basins that are bounded by the faults in the study area (Figure 10).

\subsubsection{Mountain Front Sinuosity (Smf)}

Along tectonically active mountain fronts uplifts rate prevail over erosional processes, and demonstrate low Smf values. On the other hand, dominant erosional processes along mountain-piedmont junction denote high Smf values (Keller and Pinter, 2002; Silva et al., 2003). Overall, in this study, 7 Smf values were calculated totally, 4 on the Sürgü fault and 3 on the Çardak fault. Along the eastern part of the Sürgü fault, parallel to an extending ridge, the Sürgü 1 segment depicts Lmf and Ls values of 23.465 and $18.185 \mathrm{~m}$ respectively. Thus, here the mountain front sinuosity (Smf) has been calculated as 1.29 (Figure 7). Around the southern section of the fault, at the southern boundary of the Kurucaova basin, two Smf values were also calculated. The Sürgü 2 segment yield Lmf: $23.162 \mathrm{~m}$, Ls: $15.665 \mathrm{~m}$, and Smf: 1.48, yet through the Sürgü 3, the Lmf and Ls values are 10.032 and $7.330 \mathrm{~m}$ respectively. These quantities indicate 1.37 for the Smf. The Smf calculations along the Sürgü 4 segment (the middle segment of the Sürgü fault) denote Lmf: 22.230 m, Ls: 17.085 m, and Smf: 1.30 (Figure 7). The obtained values along the Sürgü fault demonstrate that the tectonic forces are more impactful in terms of the basin development, in comparison to the erosional processes here.

Through the Çardak 1 segment, within a basin in the eastern part of the Çardak fault, Lmf and Ls were calculated as 16.693 and $13.818 \mathrm{~m}$; thus, Smf value is 1.21 (Figure 8a). Since the western part of the Çardak fault represents a curved geometry, two Smf assessments were conducted along the mountain fronts in this location (Figure 8b). Smf measurements on the Çardak 2 segment imply values of 23.323 and $16.631 \mathrm{~m}$ for Lmf and Ls respectively which provide 1.40 for Smf indice along this segment. Finally, around the western section of the Çardak fault, Lmf and Ls measured as 30.565 and $25.049 \mathrm{~m}$. Therefore, Smf for Çardak 3 segment was calculated as 1.22 (Figure 8b). The measured Smf quantities on the Çardak fault indicate that tectonic activities are effective elements in governing the basin developments along the related faults.

\subsubsection{Valley Floor Width-to-Valley Height Ratio (Vf)}

The ratio of valley floor width to valley height ratio is one of the popular and beneficial indices to evaluate the tectonic uplift rate in a region. "V" shaped valleys with low Vf values indicate high uplift rates in a region. On the other hand, high $\mathrm{Vf}$ quantities represent that the uplift rate is low, for domination of erosional processes over tectonic activities (Keller and Pinter, 2002; Silva et al., 2003). In this study, Vf values associated with the river channels along the mountain fronts were calculated; besides, it is aimed to classify the relative tectonic activities and uplift rates of the different fault segments. Thereby, Vf profiles were plotted with an approximately 180-meter interval for each valley (starting from the outlet point along the mountain front towards upstream) and Vf values calculated immaculately for each profile. In this study, a total of $122 \mathrm{Vf}$ 
values were calculated within the study area, 53 through the drainage basins associated with the Sürgü fault, and 69 along the drainage basins associated with the Çardak fault. Last but not least, Vf values averaged for each valley and mean Vf values were calculated for each segment. For this purpose, 16 valleys on the Sürgü fault and 20 valleys on the Çardak fault have been utilized (Figures 7 and 8). These values and their associated Smf values are given in Table 1.

The average Vf values for the Sürgü fault and its southern parts vary between 0.42 and 1.09 (Figure 7, Table 1). Except from the value of 1.09 obtained from a valley (S2v2) at the southern part of the fault, the Sürgü Fault's Vf values indicate high (class-1) and moderate (class-2) tectonic activity levels. The average Vf values recorded for the valleys associated with the Çardak fault range between 0.20 and 1.12 (Figure 8, Table 1). Similarly, in this section, the average Vf value calculated along solely one valley (C2v5) was higher than 1 (1.12). Apart from that, the Vf values associated with the Çardak fault indicate high (class-1) and moderate level (class-2) tectonic activity.

Some studies, state that there is a relative relationship between Vf values and Smf quantities and relative tectonic activity of faults evaluated based on this relative relation (Rockwell, Keller, \& Johnson, 1984; Silva et al., 2003). Pondering the calculated Smf and Vf values related to the Sürgü fault, it is evident that the uplift and tectonic activity rate along the Sürgü fault (the Sürgü 1 and Sürgü 4 segments) are relatively higher than the southern section of the fault (the Sürgü 2 and Sürgü 3 segments). Moreover, along the Çardak fault, it is conspicuous that the segments located in eastern and western margins (the Çardak 1 and Çardak 3) reflect higher tectonic activity and uplift compared to the middle part (the Çardak 2 segment; Table 1 and Figure 9).

A combination of the calculated Smf values and the average Vf value of each valley throughout the Sürgü and Çardak faults indicate a good correlation between Vf and Smf values with $\mathrm{R}^{2}=0.8682$ (Figure 9). Overall, the results of Smf and Vf analysis in the study area indicate that the Sürgü and Çardak faults have high tectonic activity (Class I; Figure 9).

Table 1.

Smf and average Vf quantities calculated along the mountain fronts of the Sürgü and Çardak faults.

\begin{tabular}{|c|c|c|c|}
\hline \multicolumn{4}{|c|}{ Sürgü Fault } \\
\hline $\begin{array}{l}\text { Smf } \\
\text { name }\end{array}$ & $\begin{array}{c}\text { Smf } \\
\text { value }\end{array}$ & $\begin{array}{l}\text { Valley } \\
\text { name }\end{array}$ & $\begin{array}{l}\text { Vf } \\
\text { avr. }\end{array}$ \\
\hline \multirow{3}{*}{ 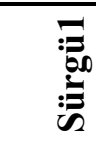 } & \multirow{3}{*}{ సે } & S1v1 & 0.49 \\
\hline & & S1v2 & 0.68 \\
\hline & & S1v3 & 0.42 \\
\hline \multirow{5}{*}{ 苛 } & \multirow{5}{*}{$\stackrel{\infty}{\underset{\sim}{-}}$} & $\mathrm{S} 2 \mathrm{v} 1$ & 0.65 \\
\hline & & $\mathrm{S} 2 \mathrm{v} 2$ & 1,09 \\
\hline & & $\mathrm{S} 2 \mathrm{v} 3$ & 0.73 \\
\hline & & $\mathrm{S} 2 \mathrm{v} 4$ & 0.61 \\
\hline & & $\mathrm{S} 2 \mathrm{v} 5$ & 0.50 \\
\hline \multirow{4}{*}{ : } & \multirow{4}{*}{$\hat{n}$} & S3v1 & 0.62 \\
\hline & & $\mathrm{S} 3 \mathrm{v} 2$ & 0.62 \\
\hline & & S3v3 & 0.65 \\
\hline & & $\mathrm{S} 3 \mathrm{v} 4$ & 0.86 \\
\hline \multirow{4}{*}{ 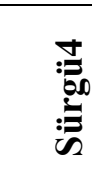 } & \multirow{4}{*}{$\stackrel{\text { r. }}{-}$} & S4v1 & 0.63 \\
\hline & & $\mathrm{S} 4 \mathrm{v} 2$ & 0.73 \\
\hline & & $\mathrm{S} 4 \mathrm{v} 3$ & 0.46 \\
\hline & & $\mathrm{S} 4 \mathrm{v} 4$ & 0.51 \\
\hline
\end{tabular}

\begin{tabular}{|c|c|c|c|}
\hline \multicolumn{4}{|c|}{ Çardak Fault } \\
\hline $\begin{array}{c}\text { Smf } \\
\text { name }\end{array}$ & $\begin{array}{c}\text { Smf } \\
\text { value }\end{array}$ & $\begin{array}{l}\text { Valley } \\
\text { name }\end{array}$ & $\begin{array}{l}\text { Vf } \\
\text { avr. }\end{array}$ \\
\hline \multirow{7}{*}{ 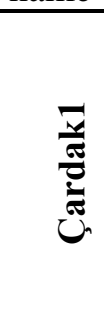 } & \multirow{7}{*}{$\vec{\sim}$} & C1v1 & 0.72 \\
\hline & & C1v2 & 0.43 \\
\hline & & C1v3 & 0.65 \\
\hline & & C1v4 & 0.48 \\
\hline & & C1v5 & 0.40 \\
\hline & & C1v6 & 0.59 \\
\hline & & C1v7 & 0.20 \\
\hline \multirow{5}{*}{ 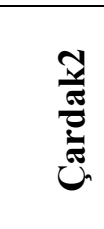 } & \multirow{5}{*}{$\stackrel{\circ}{-}$} & $\mathrm{C} 2 \mathrm{v} 1$ & 0.50 \\
\hline & & $\mathrm{C} 2 \mathrm{v} 2$ & 0.58 \\
\hline & & $\mathrm{C} 2 \mathrm{v} 3$ & 0.81 \\
\hline & & $\mathrm{C} 2 \mathrm{v} 4$ & 0.56 \\
\hline & & $\mathrm{C} 2 \mathrm{v} 5$ & 1,12 \\
\hline \multirow{8}{*}{ 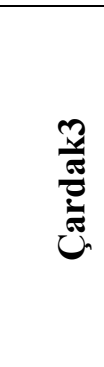 } & \multirow{8}{*}{$\underset{\sim}{\infty}$} & $\mathrm{C} 3 \mathrm{v} 1$ & 0.25 \\
\hline & & $\mathrm{C} 3 \mathrm{v} 2$ & 0.54 \\
\hline & & $\mathrm{C} 3 \mathrm{v} 3$ & 0.93 \\
\hline & & $\mathrm{C} 3 \mathrm{v} 4$ & 0.34 \\
\hline & & $\mathrm{C} 3 \mathrm{v} 5$ & 0.38 \\
\hline & & C3v6 & 0.56 \\
\hline & & C3v7 & 0.35 \\
\hline & & $\mathrm{C} 3 \mathrm{v} 8$ & 0.38 \\
\hline
\end{tabular}




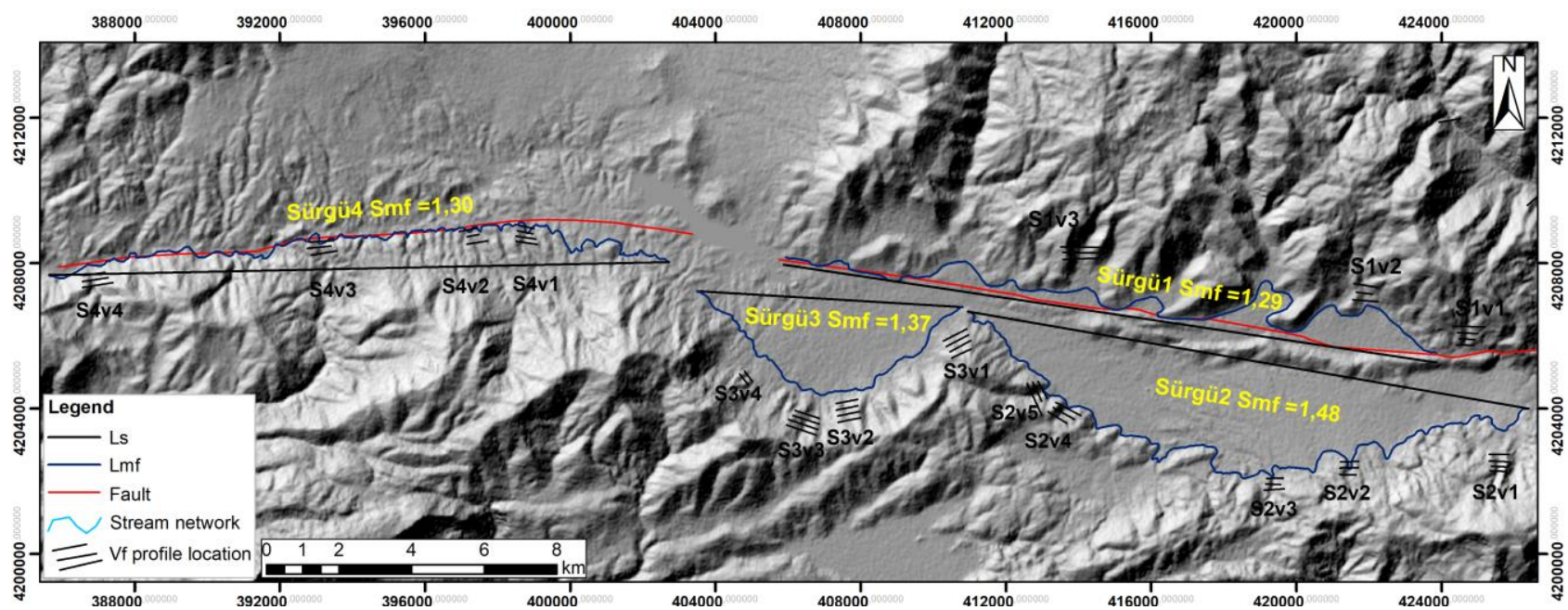

Figure 7. The calculated Smf values and locations of the Vf profiles along the Sürgü fault and associated mountain fronts located at the southern section of the fault.
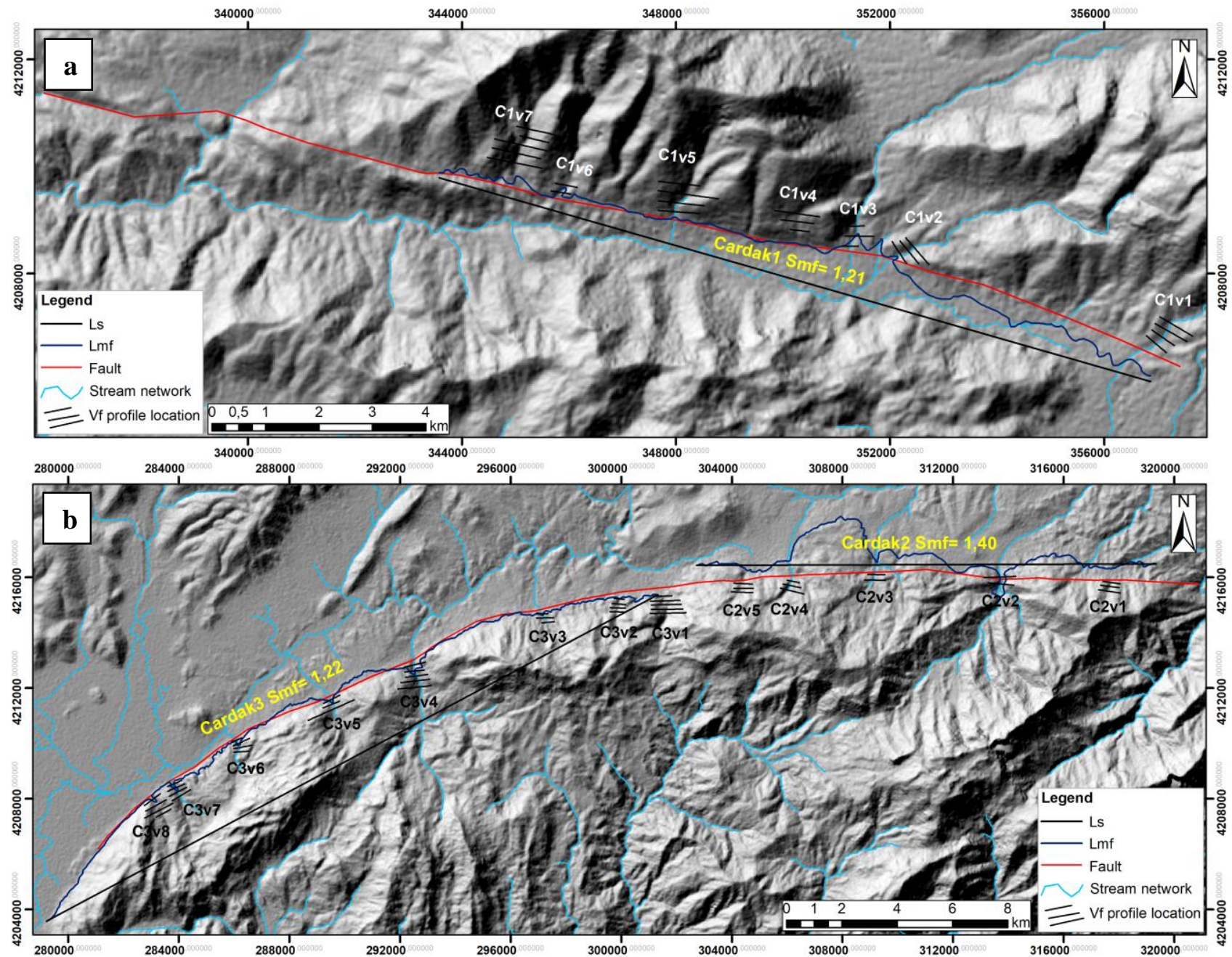

Figure 8. The Smf values calculated in the east (a) and west (b) sections of the Çardak fault and the locations of the plotted Vf profiles along the analyzed valleys. 

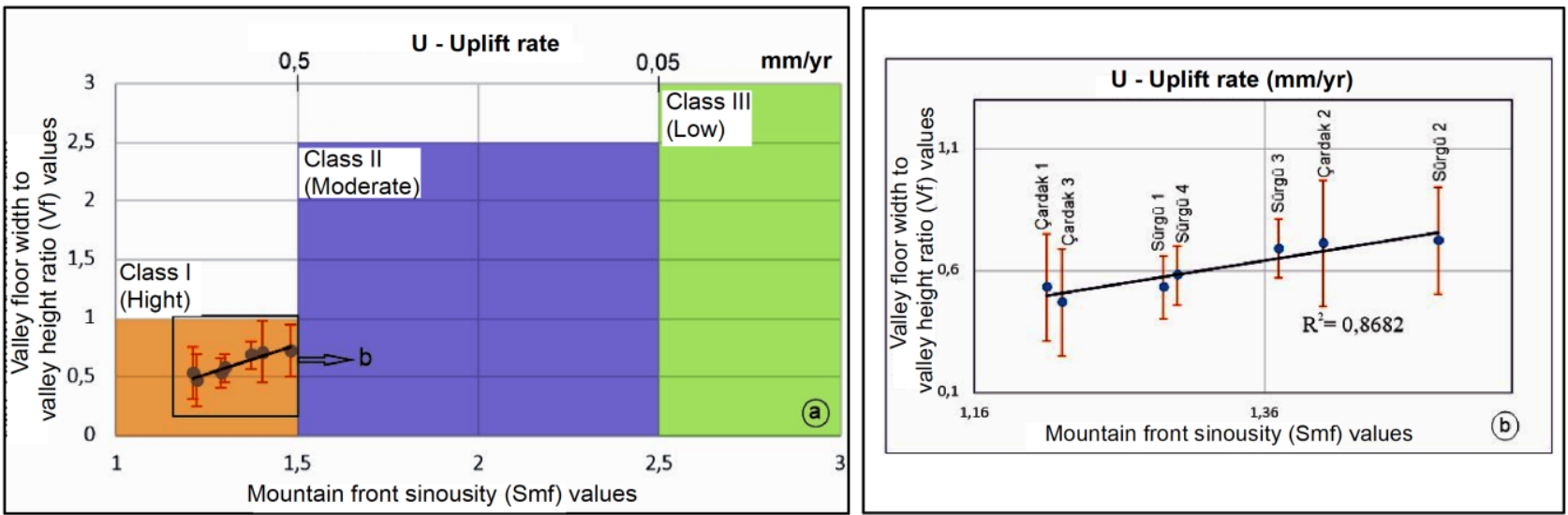

Figure 9. The graph demonstrates the uplift rates (a) and the correlation (b) of Smf and Vf values calculated along the mountain fronts in the study area (Rockwell et al., 1984).

\subsubsection{Stream Length-Gradient Index (SL)}

In this study, SL calculation interval values were defined as $10 \mathrm{~m}, 20 \mathrm{~m}$, and $50 \mathrm{~m}$ based on the length of the evaluated valley. Acquired SL values by surveying the valleys in the study area are divided into 3 tectonic classes, namely class 1: $250<\mathrm{SL}$, class 2: $150<\mathrm{SL}<250$, and class 3: SL $<150$.

As a framework of this investigation, a total number of 77 SL indices were calculated along 10 valleys, more precisely 6 on the Sürgü fault and 4 on the Çardak fault. Performed calculations started at the highest upstream point along the valleys which are positioned perpendicular to the fault's strike, and then the fault was transcended; finally, calculations at the outlet point where the stream meets the main river completed. The obtained SL values range from 5.8 to 1330.0, and the greatest anomalies were observed at the east of the Çardak fault (Çardak SL.1), across a distinct mountain front which evolved and controlled by the fault (Figures 10 and $11 b)$.

Within an area without lithological differentiations, change in morphology, and tectonic activity, the SL indice values are prospected to reflect an ascending trend without showing anomalies (Köle, 2016). Analysis of the thalweg profiles of SL indices along the Sürgü fault indicates that the Sürgü SL.0, SL.1 and SL.4 values only show minuscule anomalies and they stood at the "class 3" range in the tectonic classification (based on the SL indice anomaly classification; Figure 10). Examination of the Sürgü SL.2, SL.3, and SL.5 profiles in and around the Sürgü fault demonstrate that the SL indice values depict high anomaly values and fall in the "class 1" and "class 2" tectonic classification range (Figure 10). When the Sürgü SL.3 profile is examined, it is observed that it shows high anomaly (331.8) around the fault (Figure 11a).

SL values measured along the linear valleys shaped by strike-slip faults are expected to stand at low quantities due to the acute impacts of denudation on the rocks along the fault zone (Keller and Pinter, 2002). It was observed that the average value of SL indice (Sürgü SL.0) through a collateral valley along the fault strike in the eastern part of the Sürgü fault was only 31.

Assessment of the thalweg profiles of SL indices along the Çardak fault, which is the second active structure in the study area, represent that the values along the Çardak SL.4 valley show a trivial anomaly and difference; hence, it is stood at the "class 3" value range according to the tectonic classification based on the SL indice anomaly ratio (Figure 10). Evaluation of the Çardak SL.1, SL.2, and SL.3 profiles yield high anomaly values for the SL indice ("class 1" and "class 2" according to the tectonic classification) in and around the Çardak fault (Figures 10 and 11b). Stream length-gradient indice analysis reveals that the Sürgü and Çardak faults play an essential role in the evolution and development of the tectonic regimes in the study area. 


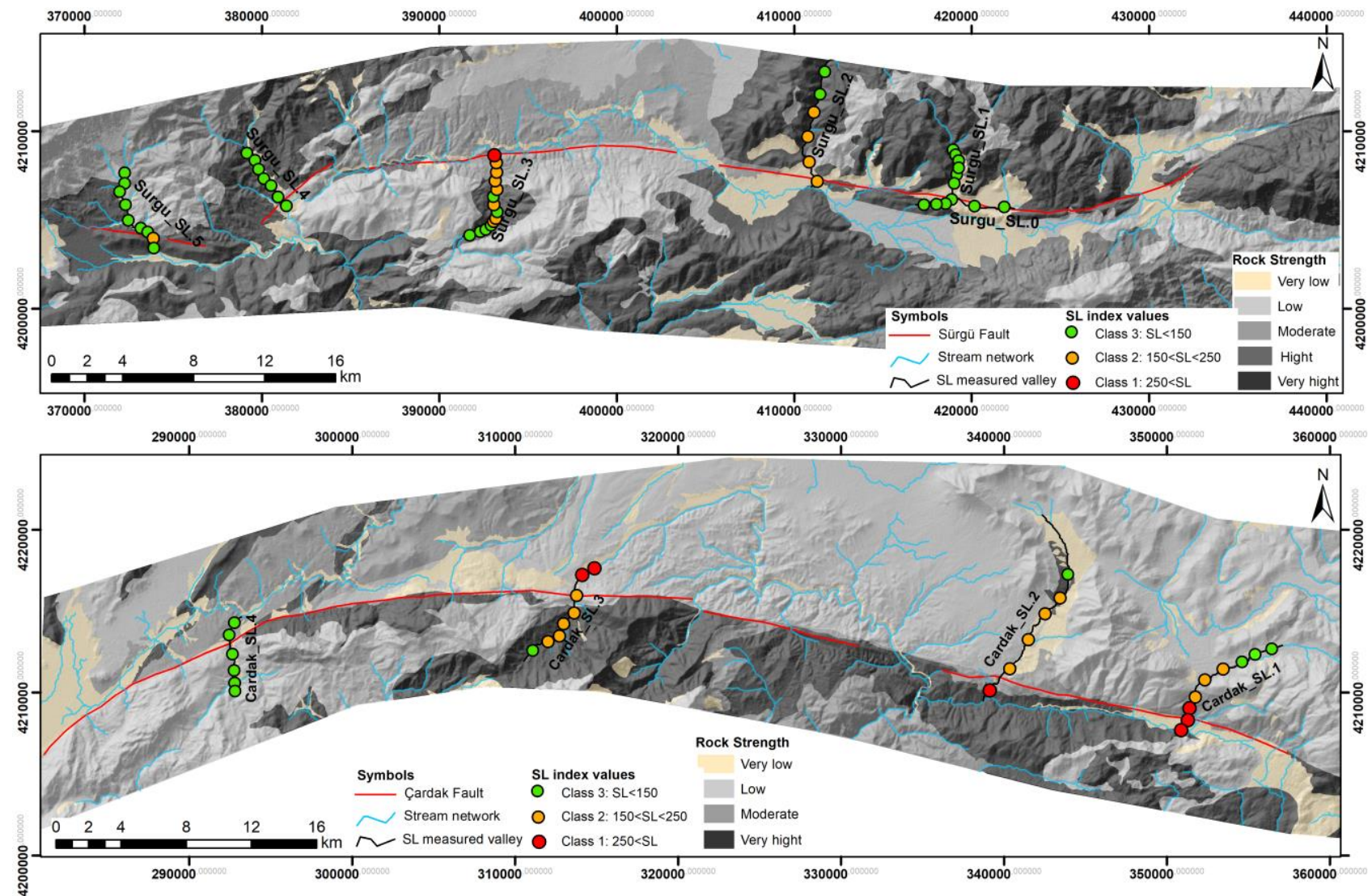

Figure 10. The map shows the locations and tectonic classes of SL indices and the rock strength classification of the different lithological units in the study area based on Selby (1980)'s fundamental rock resistance definitions.
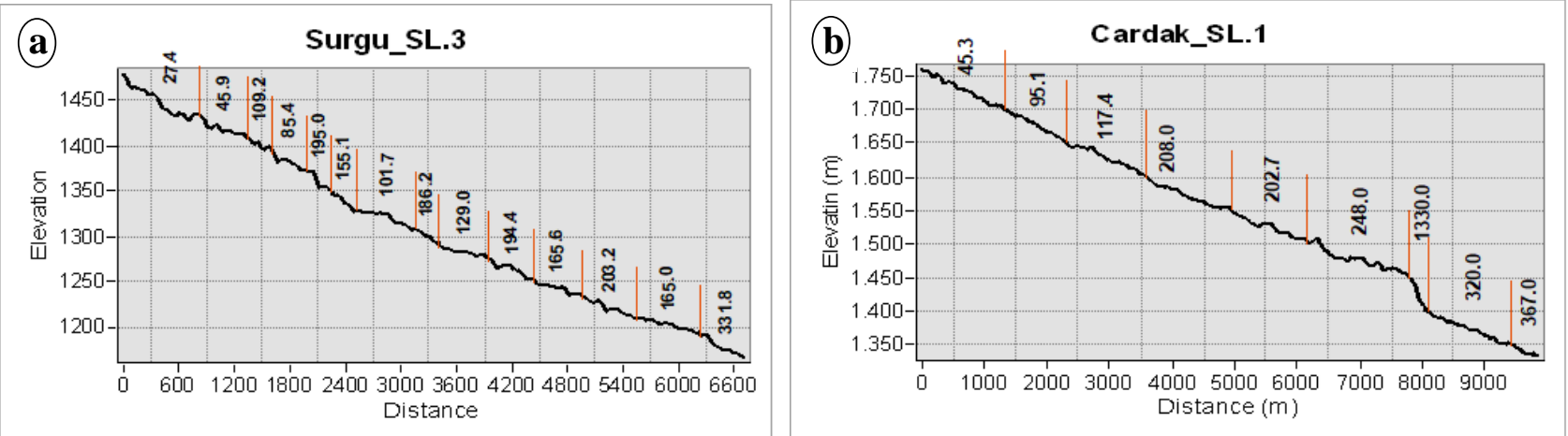

Figure 11. Longitudinal river profiles with high anomalies associated with the Sürgü (a) and Çardak (b) faults.

\section{Conclusion}

In this study, the morphotectonic properties and characteristics of the Sürgü and Çardak faults were discovered. Enlisting the field studies, Google Earth images, and the plotted stream network on the DEM data, stream offsets were detected along the Sürgü and Çardak faults at a different location within the study area. These observations reveal that the Sürgü and Çardak faults represent active sinistral strike-slip fault morphology. Within the framework of morphometric indice calculations, a total number of 7 mountain front sinuosity (Smf) values were calculated in the study area, 4 on the Sürgü fault and 3 on the Çardak fault. The variation of the Smf values between 1.21 and 1.48 indicate domination of the tectonic activity over the denudation process along the basin within the study area. In the study area, average Vf values were calculated from 16 and 20 valleys along the mountain fronts of the Sürgü fault and Çardak faults. Overall, the calculated average Vf values vary between 0.20 and 1.12 . The combination of the calculated Smf and Vf values within 
the study area indicate high activity for the Sürgü and Çardak faults. The observed high stream length-gradient indice (SL) anomalies on the Sürgü and Çardak faults and adjacent landscapes along the 77 profiles throughout 10 valleys in the study area shows that these faults play an active role in the tectonic evolution of the region. Eventually, morphometric investigations cater valuable information about the geomorphologic evolution of the region and the effects of the tectonic process on this evolution.

\section{Acknowledgement}

This study constitutes a part of Musa Balkaya's doctoral thesis. The study was supported by FDK-20192979 and 120Y102 projects which were funded by the Çanakkale Onsekiz Mart University Scientific Research Projects Coordination Unit and by the TÜBİTAK 1002 Quick Support Projects. We are grateful to ÇOMÜBAP unit and TÜBİTAK for their support. Thanks to Prof. Dr. Tolga Bekler for his contributions to the instrumental period earthquake records subject, to Dr. Taylan Sançar for theoretical background on morphometric indices and to Mehran Basmenji for english translation of the manuscript.

\section{Author Contributions}

Musa Balkaya: Conducted morphometric analysis, attended field studies and wrote the article.

Süha Özden: Contributed to data evaluation and interpretation of the results.

H. Serdar Akyüz: Attended to field studies, contributed to the evaluation of the data and interpretation of the results.

\section{Conflicts of Interest}

The authors declare no conflict of interest.

\section{References}

Ambraseys, N. (2009). Earthquakes in the Mediterranean and Middle East: a multidisciplinary study of seismicity up to 1900 . Cambridge University Press.

ASF, (2020). Alaska Satellite Facility Data Search User Manual, Retrieved from: https://search.asf.alaska.edu/\#/

Basmenji, M., Sancar, T., Dikbas, A., Boulton, S., \& Akyuz, H. S. (2021). Tectonic geomorphology of the Yatağan Fault (Muğla, SW Turkey): implications for quantifying vertical slip rates along active normal faults. DOI: http://dx.doi.org/10.3906/yer-2010-11

Baydar, O. \& Yergök, A. F. (1996). Güneydogu Anadolu-Kenar Kıvrım Kusagı-Amanos Dagları Kuzeyi ve Dogu Torosların Jeolojisi. Geological Studies Department, Ankara, 90p (unpublished).

Bedi, Y., \& Yusufoğlu, H. (2018). 1/100.000 ölçekli Türkiye Jeoloji Haritaları, Malatya-L40 paftası, no: 261, MTA Genel Müdürlüğü, Ankara.

Bull, W.B. (2008). Tectonic geomorphology of mountains: a new approach to paleoseismology. John Wiley and Sons, Oxford, $315 \mathrm{~s}$.

Çoban, M., \& Dalkılıç, H. (2018). 1/100.000 ölçekli Türkiye Jeoloji Haritaları, Şanlıurfa-M39 paftası, no: 262, MTA Genel Müdürlüğü, Ankara.

Duman, T.Y., \& Emre, O. (2013). The East Anatolian fault: geometry, segmentation and jog characteristics. GeolSoc 372:495-529. DOI: https://doi.org/10.1144/SP372.14

El Hamdouni, R., Irigaray, C., Fernández, T., Chacón, J., \& Keller, E. A. (2008). Assessment of relative active tectonics, southwest border of the Sierra Nevada (southern Spain). Geomorphology, 96(1-2), 150-173. DOI: https://doi.org/10.1016/j.geomorph.2007.08.004

Emre, Ö., Duman, T. Y., Özalp, S., Elmacı H., Olgun Ş., \& Şaroğlu F. (2013). Active fault map of Turkey with an explanatory text 1:1,250,000 scale. General Directorate of Mineral Researchand Exploration, Special Publication Series 30.

Emre, Ö., Duman, T. Y., Özalp, S., Şaroğlu, F., Olgun, Ş., Elmacı, H., \& Çan, T. (2016). Active fault database of Turkey. Bulletin of Earthquake Engineering, 1-47. DOI: https://doi.org/10.1007/s10518-016-0041-2

Guidoboni, E., Comastri, A., Traina, G., \& Rom Istituto Nazionale di Geofisica. (1994). Catalogue of Ancient Earthquakes in the Mediterranean Area up to the 10th Century (p. 504). Rome: Istituto nazionale di geofisica. 
Hack, J. T. (1973). Stream-profile analysis and stream gradient index. Journal of Research of the US Geological Survey, 1 (4), 421-429.

Herece, E. (2008). Doğu Anadolu Fayı (DAF) Atlas1. General Directorate of Mineral Research and Exploration. Special Publications, Ankara, Serial Number, 13, 359.

Khalifa, A., Cakir, Z., Owen, L., \& Kaya, Ş. (2018). Morphotectonic analysis of the East Anatolian Fault, Turkey. Turkish Journal of Earth Sciences, 27(2), 110-126. DOI: https:doi.org/10.3906/yer-1707-16

Keller, E.A., \& Pinter, N. (2002). Active tectonics: Earthquakes, Uplift, andLandscape (2nd Edn.): New Jersey, PrenticeHall, $432 \mathrm{p}$.

Koç, A. (2005). Remote Sensing Study of Sürgü Fault Zone (Malatya, Turkey). Master Thesis (Unpublished), Ankara.

Koç, A., \& Kaymakci, N. (2013). Kinematics of Sürgü Fault Zone (Malatya, Turkey): A remote sensing study, Journal of Geodynamics, 65, 292-307. DOI: https://doi.org/10.1016/j.jog.2012.08.001

KOERI-RETMC, (2021). Boğaziçi University Kandilli Observatory and Earthquake Research Institute Regional Earthquake-Tsunami Monitoring Center. Retrieved from: http://www.koeri.boun.edu.tr/sismo/zeqdb/indexeng.asp

Kop, A., Ezer, M., Bodur, M. N., Darbaş, G., Inan, S., Ergintav, S., ... \& Yalçin, C. (2014). Geochemical Monitoring Along the Türkoğlu (Kahramanmaraş)-Gölbaş1 (Adıyaman) Segments of the East Anatolian Fault System. Arabian Journal for Science and Engineering, 39(7), 5521-5536. DOI: https://doi.org/10.1007/s13369-013-0912-7

Köle, M.M. (2016). Devrez Çayı vadisinin tektonik özelliklerinin morfometrik indisler ile araştırılması, İstanbul Üniversitesi, Edebiyat Fakültesi Coğrafya Dergisi, 33, 21-36. Retrieved from: http://www.journals.istanbul.edu.tr/iucografya.

McClusky, S., Balassanian, S., Barka, A., Demir, C., Ergintav, S., Georgiev, I., ... \& Kastens, K. (2000). Global Positioning System constraints on plate kinematics and dynamics in the eastern Mediterranean and Caucasus. Journal of Geophysical Research: Solid Earth, 105(B3), 5695-5719. DOI: https://doi.org/10.1029/1999JB900351

MTA, (2014). 1/100.000 ölçekli Türkiye Jeoloji Haritaları, Elbistan-L37 ve L38, Malatya-L39 ve L40, Gaziantep-M37 ve M38, Şanlıurfa-M39 ve M40 paftaları. Maden Tetkik ve Arama Genel Müdürlüğü, Türkiye Jeoloji Veri Tabanı, Jeoloji Etütleri Dairesi Başkanlığı, Ankara.

Nalbant, S. S., McCloskey, J., Steacy, S., \& Barka, A. A. (2002). Stress accumulation and increased seismic risk in eastern Turkey. Earth and Planetary Science Letters, 195(3-4), 291-298. DOI: https://doi.org/10.1016/S0012-821X(01)00592-1

Özdemir, M. A., \& İnceöz, M. (2003). Doğu Anadolu fay zonunda (Karlıva-Türkoğlu Arasında) akarsu ötelenmelerinin tektonik verilerle karşılaştırılması. Afyon Kocatepe Ü. Sosyal B. dergisi, cilt: 5 sayı: 1

Perinçek, D., \& Kozlu, H. (1984). Stratigraphy and Structural Relations of the Units in the Afşin - Elbistan Doğanşehir Region (EasternTauros). In: Geology of TaurosBelt (eds., O. Tekeli and M.C. Göncüoğlu). MTA, p.181-198.

Reilinger, R., McClusky, S., Vernant, P., Lawrence, S., Ergintav, S., Cakmak, R., ... \& Nadariya, M. (2006). GPS constraints on continental deformation in the Africa-Arabia-Eurasia continental collision zone and implications for the dynamics of plate interactions. Journal of Geophysical Research: Solid Earth, 111(B5). DOU: https://doi.org/10.1029/2005JB004051

Rockwell, T.K., Keller, E.A., \& Johnson, D.L. (1984). Tectonic geomorphology of alluvial fans and mountain fronts near Andntura, California. Tectonic Geomorphology, 183-207.

Saber, R., Isik, V., \& Caglayan, A. (2018). Assessment of relative tectonics activity along Aras Valley (NW Iran) using morphometric indices. Paper presented at: The 36th national and the 3rd international geosciences congress, Tehran, Iran.

Sançar, T. (2018). Yüksekova Havzası'nın (Güneydoğu Türkiye) Yükselim Hızı Tarihçesi’nin Araştırılması. Türkiye Jeoloji Bülteni, 61(2), 207-240. DOI: https://doi.org/10.25288/tjb.439182

Selby, M. J. (1980). A rock mass strength classification for geomorphic purposes: with tests from Antarctica and New Zealand. Zeitschrift für Geomorphologie Stuttgart, 24 (1), 31-51.

Selçuk, A. S. (2016). Evaluation of the relative tectonic activity in the eastern Lake Van basin, East Turkey. Geomorphology, 270, 9-21. DOI: https://doi.org/10.1016/j.geomorph.2016.07.009

Silva, P.G., Goy, J.L., Zazo, C., \& Bardají, T. (2003). Faulth generated mountain fronts in southeast Spain: Geomorphologic assessment of tectonic and seismic activity. Geomorphology 50, 203-225. DOI: https://doi.org/10.1016/S0169-555X(02)00215-5

Sunkar, M., Günek, H., \& Canpolat, C. (2008). Kurucaova ve Yakın Çevresinin (Malatya) Jeomorfolojisi. Fırat Üniversitesi Sosyal Bilimler Dergisi Cilt: 18, Sayı: 2 Sayfa: 1-22, Elazı $\breve{g}$. 
Şaroğlu, F., Emre, O., \& Kuşçu, I. (1992). The East Anatolian Fault Zone of Turkey. Annalae Tectonicae 6, 99-125.

Şengör, A.M.C., (1980). Türkiye'nin neotektoniğinin esasları, Türkiye jeoloji Kurumu, Konferans serisi: 2, Ankara.

Taymaz, T., Eyidoğan, H., \& Jackson, J. (1991). Source Parameters of Large Earthquakes in the East Anatolian Fault Zone (Turkey). Geophys. J. Int. 106, 537-550. DOI: https://doi.org/10.1111/j.1365246X.1991.tb06328.X

Topal, S., Keller, E., Bufe, A., \& Koçyiğit, A. (2016). Tectonic geomorphology of a large normal fault: Akşehir fault, SW Turkey. Geomorphology, 259, 55-69. DOI: https://doi.org/10.1016/j.geomorph.2016.01.014

Topal, S. (2019). Evaluation of relative tectonic activity along the Priene-Sazlı Fault (Söke Basin, southwest Anatolia): Insights from geomorphic indices and drainage analysis. Journal of Mountain Science, 16(4). DOI: https://doi.org/10.1007/s11629-018-5274-x

Troiani, F., Galve, J. P., Piacentini, D., Della Seta, M., \& Guerrero, J. (2014). Spatial analysis of stream lengthgradient (SL) index for detecting hillslope processes: a case of the Gállego River headwaters (Spain). Geomorphology, 214, 183-197. DOI: https://doi.org/10.1016/j.geomorph.2014.02.004

Usta, D., Ateş, Ş., Çoban, M., Deveci, Ö., Ekmekyapar, A., Sağlam F. M., Vural, A., \& Dinç, S. (2018). 1/100.000 ölçekli Türkiye Jeoloji Haritaları, Șanlıurfa-M40 paftası, no: 263, MTA Genel Müdürlüğü, Ankara.

Westaway, R. (2004). Kinematic Consistency between the Dead Sea Fault Zone and The Neogene and Quaternary Left-Lateral Faulting in SE Turkey. Tectonophysics, 391, 203-237. DOI: https://doi.org/10.1016/j.tecto.2004.07.014

Yıldırım, C. (2014). Relative tectonic activity assessment of the Tuz Gölü fault zone; Central Anatolia, Turkey. Tectonophysics, 630, 183-192. DOI: https://doi.org/10.1016/j.tecto.2014.05.023

Yılmaz, H., (2002). Sürgü Fayının Neotektonik Özellikleri. Cumhuriyet Üniv. Müh. Fak. Dergisi, Seri AYerbilimleri cilt: 19 say1: 5sayfa 35-46, Sivas.

Yönlü, Ö., Altunel, E., Karabacak, V., \& Akyüz, H. S. (2013). Evolution of the Gölbaşı basin and its implications for the long-term offset on the East Anatolian Fault Zone, Turkey. Journal of Geodynamics, 65, 272-281. DOI: https://doi.org/10.1016/j.jog.2012.04.013 